\title{
CSIS Usage in School Management: A Comparison of Good and Bad Practice Schools
}

\author{
A.J. Visscher and P.P.M. Bloemen \\ University of Twente, Faculty of Educational Science and Technology, Department of \\ Educational Organisation and Management
}

Key words: School Information System, System Utilisation, School Management

\begin{abstract}
Although the implementation and use of computerised information systems is quite common in developed countries, they are mainly limited to clerical types of support. The utilisation of the potential of these systems by school management is far below what seems possible. In this study, a group of twelve schools, including good and bad practice schools, has been investigated to obtain a more detailed picture of how school managers work with these information systems and which factors seem to promote managerial system usage. System use proves to vary considerably between schools, and five factors seem to have a promoting influence in the good practice schools. Recommendations have been formulated on the basis of the results to promote the managerial use of school information systems.
\end{abstract}

\section{INTRODUCTION AND PROBLEM STATEMENT}

Research has shown that nearly all Dutch schools for secondary education have a computer-assisted school information system supporting clerical work in schools. The support of managerial activities proves to be very limited (Visscher, 1992 \& 1997; Visscher \& Bloemen, 1999). This is not unique for the Netherlands, but is a problem worldwide (Ayres et al., 1998; Visscher etal., 1999) and regrettable since schools in many countries receive more discretion to develop their own school policies. The growing autonomy of schools implies that they need to develop plans in areas where they formerly could execute policies developed at national levels. This requires that school staffacquire new skills, and get information on which they can 
base their policies. Computerised information systems can assist here by providing valuable management information. The thousand dollar question remains how the full utilisation of these systems can be accomplished.

Research into the factors promoting the use of clerical systems is limited, whereas the picture regarding the factors determining managerial system usage is even worse. Actually, we do not know of any empirical study into this topic. Therefore, this research project explores how school managers in good practice and in bad practice schools (as far as computer-assisted school management is concerned) use their computer system, and which factors seem to explain their being outliers on the positive or negative side. More specifically, the following research questions guided this study:

1. To what extent and how do school managers in good practice and bad practice schools use computer-assisted school information systems for managerial work?

2. Which factors seem to promote the managerial usage of computerassisted school information systems?

The answers to these questions were expected to form a basis for formulating guidelines, to help schools gain higher levels of computerassisted school management.

\section{THEORETICAL FRAMEWORK}

This study did not focus on structured managerial problems (for example, the construction of the timetable) for which a limited number of variables and solutions are typical, since the use of computers for solving these problems does not seem to be difficult. The research concentrated on the use of school information systems for ill-structured school management problems characterised by uncertain causes, a large number of variables that (often in combination with each other) may cause a problem, and a variety of potential remedies of which the effectiveness remains uncertain. Problem diagnosis and the search for solutions are crucial in dealing with these problems, which may be supported by the output from information systems in five ways (Visscher, 1996):

- Analysing relationships between variables, e.g. between truancy and student achievement; achievement and lesson drop out;

- Analysing patterns over time, e.g. in student intake, staff illness, truancy over several years; 
- Answering what-ifquestions, e.g. how many students will be promoted if the promotion criteria are raised? How much money will we get if the number of students decreases by $\mathrm{x} \%$ ? How many teaching staff will be needed if $\mathrm{x}$ students are promoted?;

- Policy development based on data produced by the information system; and

- Information system-based policy evaluation, e.g. to what extent has the percentage of grade repeaters increased after the promotion criteria was adapted? Has truancy increased after the timetable was changed? What was the effect of extra mathematics lessons on student achievement?

Literature research into the factors promoting the use of school information systems for solving ill-structured management problems resulted in the selection of the following factors: perceived system quality, the perceived quality of the information the system produces (Davis \& Olson, 1985; Hentschke, 1975; Stokking \& Leenders, 1992); the school management attitude towards information systems (Piercy, 1987; Visscher, 1996); the extent of training; satisfaction with training; external support; internal support (Brummelhuis, 1995; Fullan, 1992; Nolan, 1996; Visscher, 1991); the number of other school policy measures to promote system usage; the degree of school consultation on resources and on educational matters; and the extent to which school management encourages system usage (Visscher, 1992).

A positive relationship was hypothesised between each of these factors on the one hand and the degree of managerial system usage on the other.

\section{METHOD}

In this multiple case study research, it was attempted to compare a pattern found in one case (i.e. one school) with patterns in similar and contrasting cases. The research group includes extreme cases, i.e. schools that use their information system intensively for managerial work as well as secondary schools that do not do this, or only to a small degree. The goal was to find other differences between these schools that may explain why they diverge in their extent of managerial usage. A prerequisite for inclusion was that a school uses the information system for clerical work, since clerical use is a prerequisite for managerial use. Vendors of school information systems were contacted to find schools that could be asked to participate. Those schools willing to participate were screened in an interview to determine how intensively they use the computer for clerical and managerial work. Twelve of the schools that met our criteria decided to participate, which meant that 
one interview was held with the principal, and one with the system manager or a clerical staff member. A prerequisite for the interview was that the interviewee uses the information system either directly or indirectly (i.e. data are obtained from colleagues). The content of the interviews was based on the literature study and was meant to determine:

- The nature and extent of managerial use; and

- The characteristics of schools with respect to the factors that possibly promote managerial use.

The draft interview was pilot-tested and adapted accordingly. Seven schools used the so-called School+ system, and five the SCHOLIS information system. The data was analysed by qualitative data analysis methods (cf. Miles \& Huberman, 1984).

The interviews were audio-taped and transcribed into interview protocols. Respondents' answers were summarised and scored per variable per respondent on the basis of self-defined standards.

School scores for the variable 'extent of managerial use of a school information system' were computed by first allocating a score for the degree to which the school executes each of the five types of computer-assisted management support presented in the theoretical framework. Next, each of the five scores was transformed into the following labels and scores: 'not' ( 0 points), 'a little' (0.5 points), 'quite frequently' (1 point), 'much' (1.5 points), 'very much' (2 points).

For all other variables, school scores were determined by computing the average score for the two respondents of a school for a variable, and subsequently labelling the school as either 'positive', 'neutral', or 'negative' for that variable. 


\section{RESULTS}

\subsection{Extent of managerial use}

Table 1 shows to what degree the research schools execute each of the five types of computer-assisted managerial support.

Table 1. The extent per school of managerial use of school information systems

\begin{tabular}{|l|l|l|l|l|l|l|}
\hline School & $\begin{array}{l}\text { Analyse } \\
\text { relation- } \\
\text { ships }\end{array}$ & $\begin{array}{l}\text { Analyse } \\
\text { patterns } \\
\text { over time }\end{array}$ & $\begin{array}{l}\text { What-if } \\
\text { questions }\end{array}$ & $\begin{array}{l}\text { Policy } \\
\text { develop- } \\
\text { ment }\end{array}$ & $\begin{array}{l}\text { Policy } \\
\text { evaluation }\end{array}$ & Sum score \\
\hline C & V & V & V & V & V & 10 \\
\hline D & V & V & V & V & V & 10 \\
\hline H & V & Q & V & M & M & 8 \\
\hline K & M & L & V & M & M & 7 \\
\hline I & Q & Q & V & Q & Q & 6 \\
\hline A & M & M & N & M & L & 5.5 \\
\hline L & M & V & Q & N & L & 5 \\
\hline F & Q & Q & N & Q & Q & 4 \\
\hline G & Q & Q & N & Q & Q & 4 \\
\hline E & Q & Q & N & Q & N & 3 \\
\hline J & Q & N & N & N & N & 1 \\
\hline B & N & N & N & N & N & 0 \\
\hline
\end{tabular}

Legend: $\mathrm{N}=$ not; $\mathrm{L}=\mathrm{a}$ little; $\mathrm{Q}=$ quite frequently; $\mathrm{M}=$ much; $\mathrm{V}=$ very much

Table 1 shows that schools $\mathrm{C}$ and $\mathrm{D}$ very frequently execute all types of management support, and that managerial system use is (almost) nil in schools B and $\mathrm{J}$. The twelve schools can be divided in two groups (see Table 2): six strong users (scores above 5: A, C, D, H, I, K) and six schools with little managerial usage (B, E, F, G, J, L).

The two very active managerial users know which information they need, how they can get it from the system and how to use it in policy making. They investigate a wide variety of data, the relationships between them, and develop and evaluate school policy on educational and administrative matters, informed by system information.

The other four relatively intensive users (A, H, I, K) also benefit from most of the five management activities, though with (slightly) less frequency.

In the 'little usage group', only four schools use the standard system options (standard reports on scores, absences, staff, finance, in-, throughand outflux). More complex analyses the menu does not contain are not carried out in these schools. 
Almost all schools to a certain degree seem to analyse relationships between factors (though with varying intensity), especially with respect to student affairs (e.g. searching for explanations for poor student scores by studying the relationships with intake levels, truancy, lesson drop out, or the teacher). Schools that are not very active in this regard only investigate standard relationships whereas active users also analyse relationships that are not in the standard system menu.

With respect to analysing patterns over time the picture is similar. Some schools only use standard overviews, or do not make these analyses at all, whereas other schools make more complicated analyses, e.g. regarding the intake and through-put of students over time, staff absenteeism, trends in finance, etc.

The schools clearly diverge with respect to the what-ifanalyses, probably because the menus of the two information systems do not support these. Only the intensive users prove to be able to make this type of analysis, e.g. "How many student groups and teachers will we need in the next school year if student intake is x students?"

Schools also clearly differ in their policy development and evaluation activity. Some schools completely rely on human observation and judgement, others find a basis for policy development and evaluation in computer-produced data on students, finance, etc.

\subsection{Factors promoting managerial use}

Table 2 shows the relationships between the degree of managerial system use and other school characteristics. 
Table 2. The relationship per school between the degree of managerial use and other school characteristics

\begin{tabular}{|c|c|c|c|c|c|c|c|c|c|c|c|c|}
\hline \multirow[t]{3}{*}{ Other features } & \multicolumn{12}{|c|}{ Managerial use per school } \\
\hline & 10 & 10 & 8 & 7 & 6 & 5.5 & 5 & 4 & 4 & 3 & 1 & 0 \\
\hline & $\mathrm{C}$ & $\mathrm{D}$ & $\mathrm{H}$ & $\mathrm{K}$ & I & $\bar{A}$ & $\mathrm{~L}$ & $\bar{F}$ & $\bar{G}$ & $\bar{E}$ & $\mathrm{~J}$ & $\mathrm{~B}$ \\
\hline $\begin{array}{l}\text { 1. School } \\
\text { management } \\
\text { attitude }\end{array}$ & + & + & + & - & $+1-$ & + & $+/-$ & $+/-$ & + & - & + & - \\
\hline $\begin{array}{l}\text { 2. Extent of } \\
\text { training }\end{array}$ & + & + & + & + & + & + & $+1-$ & + & $+1-$ & - & - & - \\
\hline 3. Internal support & + & + & + & + & $+1-$ & + & + & + & + & $+1-$ & $+1-$ & $+1-$ \\
\hline $\begin{array}{l}\text { 4. } \begin{array}{l}\text { Consultation on } \\
\text { administrative } \\
\text { matters }\end{array} \\
\end{array}$ & + & + & + & $+1-$ & + & + & $+1-$ & $+1-$ & $+1-$ & + & $+1-$ & $+1-$ \\
\hline $\begin{array}{l}\text { 5. Consultation on } \\
\text { education } \\
\text { matters }\end{array}$ & + & + & + & + & + & + & - & + & - & + & $+1-$ & - \\
\hline $\begin{array}{l}\text { 6. Quality } \\
\text { information } \\
\text { system }\end{array}$ & - & + & - & $+1-$ & $+1-$ & - & + & $+1-$ & + & - & + & $+/-$ \\
\hline $\begin{array}{l}\text { 7. Quality system } \\
\text { information }\end{array}$ & + & + & $+/-$ & + & $+1-$ & + & + & $+1-$ & + & $+1-$ & + & $+1-$ \\
\hline $\begin{array}{l}\text { 8. Satisfaction } \\
\text { with training }\end{array}$ & + & $+1-$ & $+1-$ & + & + & - & + & $+1-$ & $+1-$ & $+1-$ & $+/-$ & + \\
\hline $\begin{array}{l}\text { 9. Promotion by } \\
\text { school } \\
\text { management }\end{array}$ & + & + & $+/-$ & - & $+1-$ & + & - & + & + & $+/-$ & $+1-$ & $+1-$ \\
\hline $\begin{array}{l}\text { 10. External } \\
\text { support }\end{array}$ & + & + & + & + & + & + & + & + & + & $+1-$ & + & + \\
\hline $\begin{array}{l}\text { 11. Promoting } \\
\text { school activities }\end{array}$ & + & $+1-$ & $+1-$ & $+1-$ & $+1-$ & + & $+1-$ & + & + & $+1-$ & - & $+1-$ \\
\hline
\end{tabular}

The expectation that intensive users score high on the eleven selected school characteristics was confirmed for only five factors. This may imply that there is a relationship between these factors and managerial use, however, given the explorative nature of the research, that remains uncertain. Moreover, even if there is a relationship, it is questionable whether the school features cause the degree of managerial system use, or the other way around. Schools hardly differ regarding the other six factors and sometimes even have a score that is contradictory to our expectations.

\subsection{School management attitude}

School managers in most good practice schools are strongly convinced of the potential of the school information system and (very) motivated for its use. 
Their attitude probably will positively influence the system usage activities of subordinates, and the resources allocated for system use.

Although in some of the 'bad practice schools' the school managers have a positive attitude towards system use, their opinions in some cases are not strongly supported by their management colleagues.

\subsection{Extent of training}

The study showed that training courses that specifically focus on managerial system usage are non-existent. In schools labelled as 'intensive users' at least one person has been trained for more than 10 (!) hours in the basic principles of system use and in programming skills (e.g. to retrieve information not included in the menu). Staff in other schools only have been trained for a few hours in standard system operations.

\subsection{Internal support}

Staff in good practice schools seem to have more system know-how. One of the staff is often experienced and supports colleagues. The six intense users also have close contacts with their system vendors (e.g. via user groups, or as a result of participation in a pilot group).

Although bad practice schools score quite high on this variable, some of them have difficulties in solving problems that go further than the standard problems; their system managers mainly focus on technical problems instead of promoting the use of applications.

\subsection{Consultation on educational and administrative matters}

Intensive users seem to consult more on educational and administrative affairs. Schools with little use speak about monthly student progress, intensive users analyse this weekly. The latter may benefit from the fact that their information systems contain valuable information on student progress and related factors.

The other six variables that were expected to have a positive relationship with system use did not to prove to differ significantly between the strong and the non-intensive system using schools.

Intensive users are more negative in their attitude towards the quality of information systems, which may be due to more experience with those systems. Lack ofuser friendliness in the systems is the major complaint (e.g. the difficulty of retrieving information not included in the menu). One cannot say that schools in general have a very positive attitude towards system quality at all. 
All schools in general are satisfied or neutral with the quality of the information produced by available systems.

Both groups of schools are more or less equally (dis)satisfied with the training they have experienced, Schools that have been supported for several days by their vendor are more satisfied since this enabled the solving of many school specific problems. General, non tailor-made training courses in which school staff were burdened with information, and where there was little room for specific questions, seem to be little appreciated.

None of the schools experienced serious difficulties in finding external help (e.g. from a help desk) in the case of problems that could not be solved by the school itself.

Only a few schools strongly try to promote system use via school policies, e.g. automation policy, and the allocation of resources for information systems is very limited.

Some school managers encourage system usage by providing information, allocating resources, or compelling data entry, however the two groups of schools do not differ significantly in this respect.

Almost all good practice schools have a positive or a neutral score on 10 of the 11 factors; only their view on the quality of the information system is less positive. A considerable number of bad practice schools have a neutral or negative score for all school features. (Satisfaction with) training and the degree of consultation on administrative matters especially score neutral or negatively. External and internal support and the opinion of information system (information) quality score relatively high.

When asked for the decisive factors for successful managerial system usage, 36 factors were mentioned. Twelve concerned the quality of the information system, eight school managers' attitudes towards information systems, and six the quality of the system information.

Problems met in system usage mainly concerned (the user friendliness of) the information system and the information it produced.

\section{CONCLUSION}

The limitations of this explorative research are clear: the outcomes concern impressions that need to be tested in large-scale research, to justify statements about the variables as well as the interrelationships between them.

The investigation of the twelve research schools yields the following impressions. Schools vary strongly in the degree to which they benefit from the managerial support they receive from computerised information systems. Two of the schools studied frequently utilise nearly all possible types of managerial support. This also goes for four schools, however they do this 
less intensively. Four schools only use a number of standard options in the menu, whereas in two schools system use is almost nil.

The study of the relationship between system use and school features suggest that five factors may play an important promoting role. System use is more intense if a school is characterised by a positive attitude from school managers towards the value of information systems, more training focused on managerial use, more internal support, and more consultation on administrative and educational affairs at school level.

\subsection{Recommendations}

The results confirm our thoughts that convincing school managers of the relevance of information systems for the functioning of their institutions, and teaching them how to use them in school decision-making processes, is important. We need management oriented training courses that have been specifically developed and tested for this purpose.

We expect that such courses, in combination with (follow-up) support, will be of utmost importance. Motivated managers will use information systems more and encourage colleagues to do so. (For a discussion of the precise characteristics such training courses should have, see Visscher \& Branderhorst (2001).)

\section{REFERENCES}

Ayres, D., Nolan, P., \& Visscher, A. (1998). Computerized school information systems: Researching New Zealand use patterns and levels of use. In C. Fulmer, \& P. Nolan (Eds.), The integration of information for educational management. Whitefield, Maine: Felicity Press.

Brummelhuis, A.C.A. ten. (1995). Models of educational change: The introduction of computers in Dutch secondary education (Doctoral Dissertation). Enschede: Universiteit Twente.

Davis, G.B., \& Olson, M.H. (1985). Management informatiesystemen [Management information systems]. Schoonhoven: Academic Service.

Fullan, M.G. (1992). Succesful school improvement: The implementation perspective and beyond. Buckingham: Open University Press.

Hentschke, G.C. (1975). Management operations in education. Berkeley: McCutchan.

Miles, M.B., \& Huberman, A.M. (1984). Qualitative data analysis: A source-book of new methods. Beverly Hills: Sage Publications.

Nolan, P. (1996). The implications of how staff handle information for the usage of school information systems. International Journal of Educational Research, 25 (4), 323-334.

Piercy, N. (1987). Management information systems. London: Croom Helm.

Stokking, K.M., \& Leenders, F.J. (1992). Heeft verspreiding van informatie zin? [Does information distribution make sense?]. Utrecht: ISOR. 
Visscher, A.J. (1991). School administrative computing: A framework for analysis. Journal of Research on Computing in Education, 24 (1), 1 - 19.

Visscher, A.J. (1992). Design and evaluation of a computer-assisted management information system for secondary schools (PhD Dissertation). Enschede: University of Twente, Department of Educational Science and Technology.

Visscher, A.J. (1996). The implications of how staff handle information for the usage of school information systems. International Journal of Educational Research, 25 (4), 323334.

Visscher, A.J. (1997). Facilities for computer-supported decision making in schools: Explanations for lack of use and proposals for improvement. In A.C.W. Fung, A.J. Visscher, B.Z. Barta, \& D.C.B. Teather (Eds.), Information technology in educational management for the schools of the future. London: Chapman \& Hall.

Visscher, A.J., \& Bloemen, P.P.M. (1999). Evaluation and use of computer-assisted management information systems in Dutch schools. Journal of Research on Computing in Education, 32 (1), 172-188.

Visscher, A.J., Fung, A., \& Wild, P. (1999). The evaluation of the large scale implementation of a computer-assisted management information system in Hong Kong schools. Studies in Educational Evaluation, 25, 1 1-3 1.

Visscher, A.J., \& Branderhorst, E.M. (2001). How should school managers be trained for managerial school information system usage? In P. Nolan, A. Fung, \& M. Brown (Eds.), Institutional improvement through information technology in educational management. London: Kluwer. 